\title{
POVERTY AND SOIL CONSERVATION EFFORTS AMONG SMALLHOLDER FARMERS IN THE CENTRAL HIGHLANDS OF ETHIOPIA
}

Chilot Yirga and RM Hassan

Department of Agricultural Economics, University of Pretoria

This study explores the incidence of poverty and plot-level perception of soil degradation, among other factors, on soil conservation behaviour of small subsistence farmers in the central highlands of Ethiopia. The study results confirm that poverty in assets significantly reduces the probability and intensity of soil-conservation efforts as measured by use of stone/soil bund structures in the highlands of Ethiopia. Perception of soil degradation, public assistance with sharing initial costs of constructing soil-conservation structures, improved security of land tenure and farmers' education and access to information on soil degradation are essential for farmers making long-term investment in conserving soil resources. On the other hand, improved access to short-term credit for the purchase of inorganic fertilizers acts as a disincentive for long-term conservation practices, an important trade-off with serious policy implications that should be carefully evaluated.

JEL O13, Q32

\section{1}

\section{Introduction}

As in most of sub-Saharan Africa (SSA), agriculture is the dominant sector in Ethiopia, contributing 48 per cent of the GDP and 90 per cent of exports, and employing 80 per cent of the labour force (MEDaC, 1999). Poverty is a pervasive problem in Ethiopia, where agriculture is the dominant sector, and an estimated 44 per cent of the total population live below the poverty line (World Bank, 2004). Poverty incidence is particularly high in rural areas where the bulk of the population ekes out a living by working the soil. Per capita income for 2004 was estimated at US\$100, with significant variations among different regions of the country (World Bank, 2004).

In Ethiopia, soil degradation is recognized as one of the most important natural resource problem increasing the on-site cost to individual farmers in terms of reduced yield, and off-site costs to society as a result of externalities (Hurni, 1987; Bojo \& Cassells, 1995; Shiferaw
\& Holden, 1998; Pender, Gebremehin \& Ehui, 2001; Sonneveld \& Keyzer, 2003). Land degradation is most serious in the highlands (areas above 1500 meters), which constitute about half of the land area of Ethiopia, contain 95 per cent of the cultivated area and support 88 per cent and 75 per cent of the human and livestock populations, respectively (Shiferaw \& Holden, 1998). A number of studies have shown that current soil loss rates on croplands stand between 42 and 100 ton/ha/year in the highlands, leading to a productivity decline of between 0.2 and 1.8 per cent per year (FOA, 1986; Hurni, 1987; Bojo \& Cassels, 1995; Sonneveld \& Keyzer, 2003). Similarly, estimated soil nutrient losses for the highlands of Ethiopia are high, exceeding $80 \mathrm{~kg}$ of N, $\mathrm{P}_{2} \mathrm{O}_{5}$, and $\mathrm{K}_{2} \mathrm{O}$ per cultivated hectare (Stoorvogel \& Smaling, 1990). As a result, crop yields have declined or, at best, stagnated and the number of food-insecure people in the country has risen (FAO, 1998).

Efforts to increase agricultural productivity, reduce poverty, contain soil erosion and reverse soil nutrient mining are believed to have been 
severely hampered by a combination of the biophysical environment, population pressure, the institutional set-up and socio-economic conditions of farmers (Reardon \& Vosti, 1995; Bojo \& Cassells, 1995; Shiferaw \& Holden, 1998; Pender Gebremehin \& Ehui, 2001; Sonneveld \& Keyzer, 2003). Key among obstacles to improving agricultural productivity is soil degradation, which has become the basic challenge constraining poor smallholder farmers from achieving an acceptable level of food security.

Population pressure has been largely responsible for land degradation in Ethiopia (Grepperud, 1996; Sonneveld \& Keyzer, 2003). The population of Ethiopia grew from 53 million in 1992 to 67 million in 2002 and is expected to reach 129 million by 2030 . While population continues to grow, however, growth in agricultural production declined from 0.7 per cent in the period between 1970-80 to 0.4 per cent in the period between 1980-92 (World Bank, 1994). High population pressure in the Ethiopian highlands led to land fragmentation, which, coupled with a lack of suitable technologies and institutional support, forced farmers to either expand farming into marginal areas and hill sides and/or mine the soil using traditional technologies that were once sustainable under low population pressure. Moreover, domestic agricultural policies in the 1970s and 1980s discriminated against the rural poor by suppressing producer prices and forcing farm households to deliver a portion of their produce to the government-controlled marketing institutions. This discouraged the adoption of improved crop as well as soil conservation practices. Agricultural inputs such as commercial fertilizers and agrochemicals were rationed through government-controlled marketing institutions during this period (Demeke, Ali \& Thomas, 1997).

Another issue linked to soil degradation, low prevalence of soil conservation technologies and lack of interest in the long-term maintenance of soil fertility among the rural poor is the insecurity of land tenure in Ethiopia (Rahmato, 2004). The institutional set-up arguably denies smallholder farmers land-tenure security and consequently hampers private investment in soil conservation and soil-fertility enhancement practices. Besides, smallholder farmers primarily concerned with securing adequate food for their familys' immediate needs tend to use low-external input and erosive farming techniques, which not only mine the soil but also jeopardize the nation's long-term food production abilities. A recent study by Holden, Shiferaw and Wik (1998) confirms that smallholder farmers in SSA have very high rates of time preference, which partly explains smallholders' reluctance to engage in long-term soil-fertility and soil-conservation practices.

Improved agricultural technologies (improved crop varieties, commercial fertilizers, agronomic practices and pestcontrol measures) have been promoted among smallholder farmers by government and nongovernment organizations (NGOs) in an attempt to address rural poverty, declining agricultural productivity and deteriorating food security. Despite these efforts, adoption of agricultural technologies by smallholder farmers across the country has remained low (Yirga Shapiro \& Demeke, 1996; Demeke, Ali \& Thomas, 1997; Croppenstedt, Demeke \& Meschi, 2003). Recognizing that benefits from improved agricultural technologies cannot be realized unless accompanied by soilconservation measures, and encouraged by the 1974 drought that devastated the rural population, the government, assisted by external donors, has launched and maintained a major public soil conservation (soil and stone bunds) works under the food-for-work programme since the 1970's. Nonetheless, adoption of soilconservation practices remains low (Shiferaw \& Holden, 1998; Gebremedhin \& Swinton, 2003; Bekele \& Drake, 2003).

Despite a growing awareness of the seriousness of the soil degradation problem, limited information is available and few analyses have been carried out on the economic impact of soil degradation, its socio-economic determinants and the consequences for the welfare of the rural poor. This is compounded by a lack of farmlevel empirical data and knowledge about the relationship between soil loss and productivity (Shiferaw \& Holden, 2001). 
This study attempts to investigate the incidence and determinants of poverty and their consequences for adoption of soil-conservation practices among the rural poor in Ethiopia. Improved understanding of socio-economic factors constraining the adoption of such practices is necessary for designing improved policy and programmes to help promote adoption of soil-conserving and nutrientenhancing farming techniques, which in turn can be expected to improve income and reduce poverty.

Section two of this paper therefore describes the study sites and methods of data collection. Section three discusses the analytical framework. The empirical models employed and the hypotheses to be tested are given in section four. The links between poverty, perception of the soil degradation problem and adoption of soil-conservation practices are investigated and results discussed in section five. The last section concludes by summarizing the main findings and highlighting the implications of the study for research and policy.

\section{2}

\section{Study area, sampling procedures and data}

This study is based on cross-section data collected from four peasant associations (PA) in the Dendi and Debre Birehan districts in the central highlands of Ethiopia during 2003. A multi-stage sampling procedure was used for purposive selection of regions, zones and districts $^{1}$, followed by a random selection of PAs within these districts and finally a sampling of households in the selected PAs.

Necessary data were collected from various sources including secondary sources, using participatory rural appraisal (PRA) and focused formal household surveys. The PRA aimed to collect qualitative information using focused group discussions with farm household heads and key informant interviews. The information from the informal survey provided useful insight into the farming systems of the areas and was subsequently used as a basis for the design and preparation of the questionnaire and sample. Formal interviews using the questionnaire were conducted in total of 229 randomly selected households managing some 1141 cultivated plots during the 2003 cropping season. Necessary data were collected at plot, farm and household levels. The collected data include plot characteristics (size, distance from residence, severity of soil degradation, fertility level, perceived plot productivity, slope); soil fertility and soil conservation practices used and production. Major socio-economic variables measured include demographic structure of households, farm size, livestock owned, access to credit, extension and improved inputs.

The study area, the highlands of the Dendi and Debre Birehan Zuria districts, is characterized by two dominant farming systems: the barley-based crop-livestock farming systems of the upper highlands lying above 2600 meters above sea level, and the tefwheat-based crop-livestock farming systems of the mid highlands lying between 2000 and 2600 meters. The soils of the study area are quite variable. In the Dendi district, Vertisols and Cambisols are more significant in the mid highlands while Nitsols predominate in the upper highlands. The major soil types of the Debre Birehan Zuria district include Andosols, Regosols and Cambisols.

By all accounts, the sample households can be considered as poor, striving to secure an adequate supply of food for the family throughout the year. Nonetheless, significant differences exist between the rural poor with regard to asset endowment. These differential levels of wealth are important determinants of households' farming practices and their vulnerability to external shocks. Group discussions with farm households reveal four wealth categories, namely high, medium, low and very low. Table 1 shows the wealth differentials identified by the community of rural households in a wealth ranking exercise. Oxen ownership ${ }^{2}$ and the capacity to lease land were singled out as the major indicators of wealth. Households ae therefore grouped into two categories, poor and less poor, based on whether or not a household has leased additional land during the study year. 
Households identified as less poor are selfsufficient in terms of meeting household food requirements, can sell grain in the local market, have enough cash to buy clothes and other necessities, use purchased agricultural inputs (agrochemicals) and cultivate additional land acquired through informal land markets. They also lend money on interest to villagers. Households identified as poor are further classified into two sub-categories, sub-category C of households owning land, and sub-category $\mathrm{D}$ of the landless or nearly landless. The poor households in sub-category $\mathrm{C}$ own land but are severely limited by insufficient traction power and cash constraints. Consequently, households in this sub-category either acquire the muchneeded pair of oxen through traditional arrangements or lease out part of their land to households who own oxen. The poor households in sub-category D constitute the landless or nearly landless households who either do not have land of their own or cannot cultivate their land due to a lack of oxen and other critical inputs such as seed and inorganic fertilizers. A peculiar feature of this sub-category ${ }^{3}$ is that most of its members are relatively young and have some formal education.

\section{Table 1}

Wealth indicators identified through group discussions with farm households, Central highlands of Ethiopia (2003)

\begin{tabular}{|c|c|c|c|c|}
\hline \multirow[t]{2}{*}{ Wealth indicators } & \multicolumn{2}{|l|}{ Less poor } & \multicolumn{2}{|l|}{ Poor } \\
\hline & $\mathbf{A}$ & B & C & D \\
\hline Oxen $^{1}$ & Two or more pairs & One pair & One ox & None \\
\hline Milking cows & $>5$ & $3-5$ & $1-2$ & $0-1$ \\
\hline Sheep & $11-50$ & $6-10$ & $2-5$ & None \\
\hline Donkeys & $2-4$ & $0-1$ & None & None \\
\hline Horses & $1-2$ & 1 & None & None \\
\hline Land use & $\begin{array}{l}\text { Most lease } \\
\text { additional land }\end{array}$ & $\begin{array}{l}\text { Some lease addi- } \\
\text { tional land }\end{array}$ & $\begin{array}{l}\text { Some lease out part } \\
\text { of their land }\end{array}$ & $\begin{array}{l}\text { Lease out all or part } \\
\text { of their land }\end{array}$ \\
\hline Fertilizer use & $\begin{array}{l}\text { Almost all use } \\
\text { close to the } \\
\text { recommended rate }\end{array}$ & $\begin{array}{l}\text { Most use at a } \\
\text { reasonable rate }\end{array}$ & $\begin{array}{l}\text { Some use at a lower } \\
\text { rate }\end{array}$ & $\begin{array}{l}\text { Do not make } \\
\text { decisions on the } \\
\text { use of fertilizer }\end{array}$ \\
\hline $\begin{array}{l}\text { Participation in off- } \\
\text { farm activity }\end{array}$ & Very few & Most & Almost all & Almost all \\
\hline Food self sufficiency & Self sufficient & Self sufficient & Not self sufficient & $\begin{array}{l}\text { All depend on the } \\
\text { market }\end{array}$ \\
\hline
\end{tabular}

3

\section{Analytical framework}

The primary concern of this paper is to estimate the consequences of poverty and other socioeconomic factors on the adoption of soil conservation practices by smallholder farmers in the central highlands of Ethiopia. Economic agents, including poor smallholder farmers, adopt a technology only when the utility or net benefit expected from adopting that technology is perceived to be significantly greater than that of remaining without the technology (Norris \& Batie, 1987). Utility cannot be directly observed. The actions of economic agents are observed through the choices they make. Suppose that $Y_{j}$ and $Y_{k}$ represent a household's utility for two choices, which are denoted by $U_{j}$ and $U_{k}$, respectively. Following Green (2000), the linear random utility model could be specified as: 
$U_{j}=\beta_{j}^{\prime} X_{i}+\varepsilon_{j}$ and $U_{k}=\beta_{K}^{\prime} X_{i}+\varepsilon_{K}$

where $U_{j}$ and $U_{k}$ are the perceived utility of technology $\mathrm{j}$ and $\mathrm{k}$, respectively; $\mathrm{X}_{\mathrm{i}}$ is a vector of the explanatory variables that influence the perceived desirability of the technology; $\beta_{j}$ and $\beta_{\mathrm{k}}$ are parameters to be estimated; and $\varepsilon_{\mathrm{j}}$ and $\varepsilon_{\mathrm{k}}$ are the error terms, assumed to be independently and identically distributed. In the case of soil conservation technologies, if a household decides to use option $\mathrm{j}$ on the $\mathrm{i}^{\text {th }}$ plot, it follows that the perceived utility or benefit from option $\mathrm{j}$ is greater than the utility from other options (say k) depicted as:

$$
U_{i j}=\left(\beta_{j}^{\prime} X_{i}+\varepsilon_{j}\right)>U_{i k}=\left(\beta_{K}^{\prime} X_{i}+\varepsilon_{K}\right), k \neq j
$$

The probability that a household will adopt option $\mathrm{j}$ among the set of soil conservation practices could then be defined as:

$$
\begin{aligned}
& P(Y=1 \mid X)=P\left(U_{i j}>U_{i k}\right) \\
& =P\left(\beta_{i}^{\prime} X_{i}+\varepsilon_{j,}-\beta_{k} X_{i}-\varepsilon_{k}>0 \mid X\right) \\
& =P\left(\beta_{j}^{\prime} X_{i}-\beta_{k} X_{i}+\varepsilon_{j}-\varepsilon_{k}>0 \mid X\right) \\
& =P\left(\beta^{*} X_{i}+\varepsilon^{*}>0 \mid X=F\left(\beta^{*} X_{i}\right)\right.
\end{aligned}
$$

where $\mathrm{P}$ is a probability function; $\mathrm{U}_{\mathrm{ij}}, \mathrm{U}_{\mathrm{ik}}$ and $\mathrm{X}_{\mathrm{i}}$ are as defined above; $\varepsilon^{*}=\varepsilon_{j}-\varepsilon_{k}$ is a random disturbance term; $\beta^{*}=\left(\beta_{j}-\beta_{k}^{\prime}\right)$ is a vector of unknown parameters which can be interpreted as the net influence of the vector of independent variables influencing adoption; and $F\left(\beta^{*} X_{i}\right)$ is the cumulative distribution function of $\varepsilon^{*}$ evaluated at $\beta^{*} X_{i}$. The exact distribution of $\mathrm{F}$ depends on the distribution of the random disturbance term $\varepsilon^{*}$. Depending on the assumed distribution that the random disturbance term follows, several qualitative choice models such as a linear probability model, a logit model or a probit model can be estimated (Green, 2000).

The utility maximization framework postulated above suggests that a host of factors, including household, farm, plot and institutional variables, that impinge on a household's welfare are likely to determine its capacity to invest in soil-degradation control practices. Previous research on farmers' adoption of new technologies, including soil conservation, considered perception of the problem or constraint, in this case soil degradation, profitability of the proposed technology, household and farm characteristics, attributes of the technology and institutional factors such as land tenure, access to markets, information and credit (Ervin \& Ervin, 1982; Feder, Just \& Zilberman, 1985; Shiferaw \& Holden, 1998; Bekele \& Drake, 2003; Gebremedhin \& Swinton, 2003). Despite the fact that most decision-making processes concerning innovation adoption involve a multistage procedure, most adoption studies, including those focussed on soil conservation, often consider the process as a single stage. Dimara and Skuras (2003) argue that the basic tenet of a single-stage decision-making process characterizing dichotomous adoption decision models is a direct consequence of the full information assumption embedded in the definition of adoption ${ }^{4}$. However, the full information assumption is often violated and hence analysis of the adoption decisions using logit, probit and tobit models may suffer from model misspecifications (Dimara \& Skuras, 2003). In this study, the adoption-decision process is viewed as involving two stages. First, the household needs to perceive the soil loss problem and decide whether to use a conservation practice or not. Then, conditional on decision to participate, the household decides on the level or intensity of participation (proportion of area receiving soil conservation treatment).

In the highlands of Ethiopia, smallholder subsistence farmers manage several small plots of land scattered across a topo-sequence which differ in soil type, fertility level, degree of slope and other plot-specific features, suggesting perception of the soil degradation problem likely to vary from one plot to the other. Studies in the United States (US) have shown that areawide opinions held by farmers about soil degradation tend to differ significantly from farm-level opinions (Gould, Saupe \& Klemme, 1989). Studies by Shiferaw and Holden (1998) in the central highlands of Ethiopia and Bekele and Dark (2003) in the eastern highlands of Ethiopia all emphasize the importance of plotlevel perceptions of soil degradation on the adoption of soil-conservation practices.

Another issue often overlooked in the adoption literature is the link between poverty and the adoption decision. Although poverty, 
perception of soil degradation and adoption of soil conservation are jointly determined, these relationships are often analysed separately or at best in partial combinations. Poverty is pervasive among smallholders in Ethiopia and unsustainable farming patterns are linked to poverty, due in part to skewed access to productive resources, markets and other supporting services. Also, smallholder subsistence farmers manage several spatially scattered and heterogeneous plots of land. In light of these factors, this study adopts a twostage approach to analysing the consequences of poverty and other socio-economic factors on the adoption of soil-conservation practices by smallholder farmers in the highlands of Ethiopia.

\section{4}

\section{Empirical models and variables}

This section has two sub-sections. The fist subsection specifies the empirical models adopted in this study for predicting the consequences of poverty and other socio-economic factors on adoption of soil conservation by smallholder farmers in the highlands of Ethiopia. The second sub-section discusses the variables included in the empirical models.

\subsection{Empirical models}

We first specify a perception model that explores the factors that influence smallholder farmers' awareness of the soil-degradation problem. Then a Tobit model is used to explore the links between poverty, perception of soil degradation and intensity of use of soilconservation practices by smallholder farmers.

\subsubsection{The perception empirical model}

The first stage of our analysis is concerned with the factors influencing the perception of soil degradation among smallholder farmers in the central highlands of Ethiopia. As noted above, smallholder subsistence farmers in Ethiopia tend to manage several small plots of land susceptible to various degrees of soil erosion. Hypothetically then, smallholder farmers' perception of the soil-degradation problem may differ from one plot to the other, and plot-level perceptions of soil degradation are likely to correlate with the use of soil-conservation practices. To investigate the influence of hypothesized variables on perceptions of soil degradation among smallholder farmers, a binary probit model can be used.

$$
\begin{aligned}
& Z_{1}^{*}=\gamma_{0}+\gamma^{\prime} X_{1}+\varepsilon_{1}, \\
& Z_{1}=1 \text { if } Z_{1}^{*}>0,0 \text { otherwise }
\end{aligned}
$$

where $Z_{1}^{*}$ is a latent variable that indexes the combined effect of $X_{1}$ independent variables; $\mathrm{Z}_{1}$ is a binary variable denoting the perceived severity of soil degradation, where 1 represents moderate/severe degradation and 0 otherwise; $\gamma$ is a vector of coefficients; and $\varepsilon_{1}$ is an independently and normally distributed error term with mean 0 and variance $\sigma^{2}$. Details of the variables included in the probit perception model are discussed in section 4.2.1

\subsubsection{The soil-conservation adoption model}

This section models the second stage of the adoption-decision process. It analyses the influence of poverty and plot-level perception of soil degradation on adoption of soil conservation in the central highlands of Ethiopia. The intensity of use of stone/soil bunds, measured as the length of stone/soil bunds, is a censored continuous variable. The censoring arises because not all sample households use stone/soil bunds. Even those households who report having constructed stone/soil bunds may not have done so on all of the plots under their management. Application of ordinary least square (OLS) to such censored data renders the estimates biased. The appropriate model suggested and often used in the literature is the tobit model (Long, 1997; Vella, 1998; Green, 2000). The tobit model, a more general version of the probit model, estimates not only the probability of adoption (as in the probit model) but also the value of the continuous response for the case when:

$$
\begin{aligned}
& Z_{2}^{*}=\beta^{\prime} X_{2}+\varepsilon_{2} \\
& Z_{2}=Z_{2}^{*} \text { if } Z_{2}^{*}>0,0 \text { otherwise }
\end{aligned}
$$

where $\mathrm{X}_{2}$ is an $\mathrm{N} * 1$ vector of explanatory factors; $\beta$ is a vector of coefficients; and $\varepsilon_{2}$ is independently and normally distributed error 
term with mean 0 and variance $\sigma^{2} \cdot Z_{2}^{*}$ is a latent variable that indexes the combined effect of $\mathrm{X}_{2}$ independent variables and $\mathrm{Z}_{2}$ is the variable that is actually observed, the length of stone/soil bund.

Earlier studies such as Ervin and Ervin (1982) use the perception variable directly in the adoption equation, whereas later studies by Gould, Saupe and Klemme (1989) and Shiferaw and Holden (1998) use the predicted values from the perception model as regressors in the adoption model. In this study, following Gould, Saupe and Klemme (1989) and Shiferaw and Holden (1998), the predicted value from the probit perception model is used in the tobit model along with other regressors.

Of major interest in this study is the link between levels of poverty and adoption of soilconservation measures controlling for other independent variables. A number of the candidate explanatory variables (right-hand side) of the adoption process to be studied correlates strongly with the poverty incidence variable. Inclusion of these variables along with the variable measuring incidence of poverty in the right-hand side of the tobit equation might result in biased and inconsistent parameter estimates due to endogeneity. The endogeneity problem can be adequately dealt with using a two-stage estimation procedure or using the technique of instrumental variables (Green, 2000). In this study, we employ a two-stage estimation procedure to deal with the endogeneity problem and estimate the consequences of poverty, perception of soil degradation and other variables on the intensity of use of stone/soil bunds. In the first stage a probit model that relates the incidence of poverty with instrumental variables provides the predicted values of poverty incidence that index the likelihood of being poor. In the second stage, the predicted poverty variable from the first stage are used along with other variables to estimate the parameters of the tobit adoption model. The two-stage estimation procedure is given by:

$Y_{1}^{*}=\alpha_{0}+\alpha W+v_{1}$,

$Y_{1}=1$ if $Y_{1}^{*}>0,0$ otherwise

$Z_{3}^{*}=\beta_{0}+\beta_{1} \hat{Z}_{1}+\beta_{2} \hat{Y}_{1}+\beta_{3}^{\prime} X_{3}+\varepsilon_{3}$
$Z_{3}=Z_{3}^{*}$ if $Z_{3}^{*}>0,0$ otherwise (7)

Equation (6) is a probit model that relates incidence of poverty with $\mathrm{S}<1$ vector of instrumental variables $(\mathrm{S}<\mathrm{N})$; á is a vector of coefficients and an $v_{1}$ is independently and normally distributed error term with mean 0 and variance $\sigma^{2}$. The included instrumental variables represent factors that influence farmers' ability to lease land $\left(\mathrm{Y}_{1}\right)$, which is used to classify farming households as poor and less poor. Equation (7) represents a tobit regresssion model for the intensity of stone/soil use; $Z_{1}$ is the predicted values from the perception model (first stage adoption model given by equation 5); $\hat{Y}_{1}$ is the predicted value of the incidence of poverty which indexes the probability of being poor; $\mathrm{X}_{3}$ is an $\mathrm{N} * 1$ vector of explanatory factors; $\hat{a}$ is a vector of coefficients; and $\varepsilon_{3}$ is an independently and normally distributed error term with mean 0 and variance $\sigma^{2}$. Detailed discussion of the explanatory variables included in the tobit model is provided in section 4.2.2 and summarized in Table 2.

Maximum likelihood methods (MLE) are required for estimating both the probit and tobit model parameters. One major concern with the ML estimation of the tobit model, however, is its sensitivity to violations of the assumption of homoscedasticity and normality of the errors (Long, 1997; Vella, 1998; Green, 2000). In both cases, the Huber-White-sandwich estimators of variance are used to correct for possible heteroscedasticity of unknown form. Furthermore, to account for the possible error correlation arising from lack of independence, since the same household manages several plots, the variance co-variance matrix in the tobit model is modified through clustering (White, 1980; Vella, 1998).

\subsection{Choice of variables and hypotheses to be tested}

\subsubsection{Variables used in the perception probit model}

Previous studies show that household, farm, plot and institutional factors largely determine the perception of the soil-degradation problem (Ervin \& Ervin, 1982; Norris \& Batie, 1987; 
Gould, Saupe \& Klemme, 1989; Shiferaw \& Holden, 1998; Bekele \& Drake, 2003).

Among the human capital factors relevant to the study area are the age and education level of the head of the household. Higher education is believed to be associated with the ability to obtain, process and utilize new information, suggesting that household heads with higher levels of education will be highly likely to perceive soil degradation and subsequently adopt soil-conservation practices. Older and more experienced farmers are also expected to have a better perception of the soil-degradation problem than young and relatively inexperienced farmers.

Farm characteristics hypothesized to influence perception in this study include plot size, number of plots (parcels) owned, distance of plot from the homestead and plot slope. The impact of soil erosion may be more easily noticed on a large plot than on a small (micro) plot. Other things being equal, the steeper the plot slope the higher the erosion hazard. Physical size and slope of a plot, therefore, are expected to have a positive association with perception of the soil-degradation problem. Plots located far from farmers' residences are less likely to be closely monitored compared to plots located a short distance from residences. Hence, plot distance is expected to be negatively associated with perception of soil degradation.

Among the institutional variables that have a bearing on perception of the soil-degradation problem are access to information and project assistance, which are likely to be positively related with perception of soil degradation.

\subsubsection{Variables used in the tobit adoption model}

Based on investment theory, previous studies and analyses of the agriculture sector of Ethiopia, perceptions of soil degradation, capacity to invest (i.e. poverty), and farm, plot and institutional variables are hypothesized to influence adoption and intensity of use of stone/ soil bunds.

Recognition of erosion has been found to positively influence conservation behavior in a number of studies (Gould, Saupe \& Klemme, 1989; Shiferaw \& Holden, 1998; Bekele \&
Drake, 2003). Hence, the higher the predicted probability of perception of soil degradation, the more likely the intensity of use of stone/soil bunds is expected to be.

Household attributes often considered to impact on the adoption decision to varying degrees include age, education level of the household head, family size and wealth (livestock ownership and type of house). The effect of age of the farmer on the adoption decision is considered as a composite effect of farming experience and planning horizon. Many studies equate narrow planning horizons with older, more experienced farmers who may be reluctant to take up new opportunities or adopt soil-conservation practices that may not yield immediate benefits, whereas younger farmers, being more educated on the average and having longer planning horizons, may be more likely to take up new opportunities or invest in soil conservation. On the other hand, greater experience could lead to better knowledge of the farming system, which could in turn lead to more accurate assessment of available opportunities. Hence, considering these factors, the effect of the age of the household head, a proxy for years of experience in farming, cannot be signed in the empirical model a priori. Higher education is believed to be associated with the ability to obtain, process and utilize new information, suggesting that household heads with higher levels of education will be highly likely to adopt soil-conservation practices.

Wealth is believed to reflect the past achievements of households and their ability to bear risk. Previous studies in Ethiopia use the type of house a household owns (corrugated or grass-roofed) and the number of livestock as proxies for the wealth of the household (Yirga, Shapiro \& Demeke, 1996; Shiferaw \& Holden, 1998). Livestock plays a very important role in the mixed crop-livestock farming systems of the highlands. First, it serves as a store of value, which can be easily traded to meet a household's cash needs in emergencies. Second, since oxen are the major source of traction power, livestock plays a crucial role in timely land preparation and planting, which consequently determine land productivity. 
Third, livestock provides the manure required for the maintenance of soil fertility. Therefore, the number of livestock per unit of land owned is hypothesized to be positively associated with the use of soil-conservation practices.

Large family size is normally associated with a higher labour endowment that can enable a household to accomplish various agricultural tasks more efficiently, thus raising productivity. Also, households with large families are often forced to divert part of the labour force to offfarm activities. Farmers with off-farm income are less risk-averse than farmers without sources of off-farm income. Off-farm activities may also reduce liquidity constraints, thus enabling households to purchase farm inputs. Hence, offfarm income is hypothesized to be positively associated with the use of soil-conservation practices.

Farm and plot characteristics hypothesized to influence adoption of soil-conservation practices in this study are plot size, number of plots (parcels) owned (a proxy for farm size), distance of plots from the homestead and plot slope. The physical size of a plot may have a range of influences on adoption of soilconservation practices. For instance, the area taken up by soil-conservation structures might potentially initially reduce crop output and may eventually discourage adoption of such structures. On relatively large plots, a household may not be concerned with the potential area loss due to adoption of soil-conservation structures and subsequent reduction of crop output compared to the owners of small plots. Physical structures on small plots of land can also cause inconveniencies for oxen ploughing (Shiferaw \& Holden, 1998). Hence, plot size is expected to be positively related to adoption of soil-conservation practices. As for the perception probit model, plot steepness is also expected to be positively related to adoption of these techniques.. Distance of a plot from a household's residence may influence households' investment decisions in two ways. First, distance means higher opportunity cost in terms of labour time lost travelling to and from a plot and hence a disincentive to investment in soil-conservation technologies involving substantial labour inputs. Second, plots located far from farmers' residences are high-risk investments as the chance of losing these plots is higher in the event of land redistribution. Hence, plot distance is expected to be negatively associated with the use of stone/ soil bunds.

Institutional factors often considered to impact on technology adoption by smallholder farmers are access to information ${ }^{5}$, institutional credit, off-farm employment and land tenure. Direct government involvement in the construction of soil and water conservation technologies on farmers' fields has also been cited as having considerable positive impact on the adoption decision (Gebremedihn \& Swinton, 2003; Bekele \& Drake, 2003).

There is mixed evidence about the impact of land ownership on incentives to adopt a new technology. A number of studies show that land ownership increases incentives by lengthening planning horizons and increasing the share of benefits accruing to adopters while lowering the rates of time preference. It is generally held that renters of farmland are less likely to invest in conservation practices because short-term leases reduce the incentive to maintain the productivity of rented land (Norris \& Batie, 1987; Soule, Abebayehu \& Keith, 2000). In Ethiopia, despite the fact that land is public property under the custody of the government, informal land markets thrive where smallholder farmers either lease land on a cash- or sharecropping basis. Nevertheless, given past experience and the widely held view that land redistribution is a fact of life as long as land remains public property, there remains much uncertainty concerning tenure security. Nevertheless, adoption of stone/soil bunds that yield benefits over a couple of years are hypothesized to be used more widely on owned plots (plots allotted to a household directly by PA officials) than on rented or share-cropped plots.

The variable district represents the agricultural potential of the study locations. The Debre Birehan district is considered as more of a highly degraded, low-potential agricultural area than the Dendi district. Households in the Debre Birehan district are thus more likely to 
adopt soil conservation than households in the Dendi district.

The influence of poverty on intensity of use of stone/soil bunds among the rural poor is not clear. The poorest of the poor, whose main objective is securing adequate food for the family, may be less likely to use stone/soil bunds and hence more likely to deplete the soil more than the less poor, whose very survival may not be at stake. On the other hand, the poorest of the poor, who may have limited opportunities to close shortfalls in a year's production, are more likely to anticipate the negative impacts of soil degradation and invest in soil conservation. Therefore, the influence of poverty on adoption of soil conservation practices may not be predicted a priori.

Poverty is difficult to measure and no single measurement captures the incidence of poverty adequately. Measuring poverty is particularly difficult in rural Ethiopia, where the dominant source of livelihood is subsistence farming and where factor markets are incomplete or totally missing (Shiferaw \& Holden, 1998; Teklu \& Lemi, 2004). In this study, rural households are classified as poor and less poor based on whether or not they have leased additional land through the informal land market. Studies in Ethiopia show that households participate in the informal land market. A recent study by Teklu and Lemi
(2004) shows that farmers with low asset positions, especially traction power, large number of dependents, poor nutritional status and female-headed households, are more likely to lease out land. In a study that explores the twin objectives of food aid, targeting the most needy and at the same time addressing resource conservation in Northern Ethiopia, Gebremedhin and Swinton (2000) use the variable "lease-out", i.e. whether or not a household leases out land, as an indicator of inadequate resources for cultivating the land. Given the scarcity of land in the highlands and the higher likelihood of leasing land among the less poor who not only have access to traction power but also to other inputs (e.g. commercial fertilizer, improved seeds and herbicides) critical for cultivation, the capacity to lease land could serve as a good proxy for classifying households as poor and less poor.

Variables hypothesized to influence adoption of soil-conservation practices but highly correlated with incidence of poverty include the age and education level of the head of the household, wealth status (measured as livestock and type of house owned), participation in offfarm activities and location. These variables are used as instrumental variables to predict incidence of poverty in the two-stage estimation procedure.

\section{Table 2}

Definition of variables hypothesized to condition perceptions of soil degradation and intensity of stone/soil bund use among smallholder farmers in the central highlands of Ethiopia

\begin{tabular}{|l|l|l|}
\hline Variable & Description & Values \\
\hline Age & Age of the head of the farm HH & Years \\
\hline Education & Level of formal schooling attained by the head of the HH & Highest grade attend \\
\hline Off-farm & $\begin{array}{l}\text { If the head of the HH or family member have access to } \\
\text { Fffarm }\end{array}$ & $1=$ yes, $0=$ no \\
\hline $\begin{array}{l}\text { Family size } \\
\text { unit of land }\end{array}$ & Number of family members of a HH & Number \\
\hline $\begin{array}{l}\text { House type } \\
\text { Plot area }\end{array}$ & Type of house where HH dwells & TLU per unit of land owned \\
\hline Plot distance & The distance of a plot from homestead & $\begin{array}{l}\text { Corrugated iron roofed }=1 \\
\text { Grass thatched roofed }=0\end{array}$ \\
\hline
\end{tabular}




\begin{tabular}{|c|c|c|}
\hline Slope & Slop of a plot & $1=$ high, $0=$ flat \\
\hline $\begin{array}{l}\text { Perception of } \\
\text { soil degradation }\end{array}$ & Farmer's perception of the severity of soil loss on a plot & $\begin{array}{l}1=\text { medium } / \text { severe, } 0=\text { none } / \\
\text { light }\end{array}$ \\
\hline $\begin{array}{l}\text { Extension } \\
\text { package }\end{array}$ & $\mathrm{HH}$ participation in package programmes & Number of years involved \\
\hline Assistance & $\begin{array}{l}\text { If } \mathrm{HH} \text { has received assistance from government/NGO for } \\
\text { constructing conservation structures }\end{array}$ & $1=$ yes, $0=$ no \\
\hline Credit & $\begin{array}{l}\text { If a } \mathrm{HH} \text { has access to institutional credit for } \\
\text { inorganic fertilizer }\end{array}$ & $1=$ yes, $0=$ no \\
\hline Tenure & If plot is owned or rented/share-cropped & $1=$ owned, $0=$ otherwise \\
\hline District & Dendi and Debre Berihan & $\begin{array}{l}1=\text { Debre Berihane } \\
0=\text { Dendi }\end{array}$ \\
\hline
\end{tabular}

Note: $\mathrm{HH}=$ household

5

\section{Results and discussion}

\subsection{Results for the probit perception model}

Results for the probit perception model are given in Table 3. The Wald Chi-square statistics are significant $(\mathrm{P}<0.0000)$, suggesting the strong explanatory power of the model. The considered household characteristics, and the age and educational level of the head of the household, though they have the expected signs, are not statistically significant. On the other hand, among the plot characteristics hypothesized to influence perceptions of soil degradation, plot slope and distance are found significant. Other things being equal, the likelihood of perception of soil degradation is higher by 35 per cent on steeper plots compared to flat plots. The distance of a plot from the homestead, although statistically significant with the expected sign, has very little effect on the likelihood of perception. The physical size of the plot, however, appears to have no influence on perception of soil degradation.

\section{Table 3}

Results of the probit analyses of the determinants of perception of soil degradation among smallholder farmers in the central highlands of Ethiopia (2003)

\begin{tabular}{|l|c|c|c|c|}
\hline Variables & & & \multicolumn{2}{|c|}{ Marginal effects } \\
\hline & Coefficient & P-level & Perception index & P-level \\
\hline Constant & -0.3380 & 0.145 & N.A & 0.468 \\
\hline Age & 0.0031 & 0.468 & 0.0011 & 0.464 \\
\hline Education & 0.0190 & 0.464 & 0.0069 & 0.216 \\
\hline Plot area & 0.1436 & 0.215 & 0.0525 & 0.018 \\
\hline Distance to plot & $-0.0057^{* *}$ & 0.018 & $-0.0021^{* *}$ & 0.000 \\
\hline Slope & $1.0017^{* * *}$ & 0.000 & $0.3523^{* * *}$ & 0.035 \\
\hline Extension package & $0.0731^{* *}$ & 0.036 & $0.0267^{* *}$ & 0.000 \\
\hline $\begin{array}{l}\text { Project/government } \\
\text { assistance }\end{array}$ & $0.9405^{* * *}$ & 0.000 & $0.2648^{* * *}$ & \\
\hline
\end{tabular}




\begin{tabular}{|l|c|l|l|l|}
\hline Diagnostics & & & & \\
\hline $\begin{array}{l}\text { Number of } \\
\text { observations }\end{array}$ & 1141 & & \\
\hline Wald Chi-Square & $111.29^{* * *}$ & & & \\
\hline Pseudo R-Square & 0.1459 & & & \\
\hline $\begin{array}{l}\text { Log pseudo- } \\
\text { likelihood }\end{array}$ & -640.2330 & & & \\
\hline
\end{tabular}

Dependent variable: moderate/severe $=1$, nil/light $=0 ;$ N.A. $=$ Not applicable

$* * *, * *, *$ represent significant at 1 per cent, 5 per cent and 10 per cent probability levels, respectively

Government assistance for initial construction of soil-conservation practices positively and significantly influences perception of soil degradation. The chances of perception of soil degradation are higher by 26 per cent for a household receiving public assistance compared to a household that does not receive such assistance. Similarly, participation in a package extension programme, measured by the number of years a household has participated in the programme, positively and significantly correlates with the likelihood of perception. In Ethiopia, agricultural extension services provided by the MOA are a major source of information on agriculture and natural-resource conservation. The results therefore confirm the hypothesized positive role that extension plays in raising awareness of the extent of naturalresource degradation in general and soil degradation in particular.

\subsection{Consequences of poverty and plot- level perceptions of soil degradation for soil-conservation adoption}

\subsubsection{Adoption of soil-conservation practices}

Soil-conservation measures widely practised and promoted by the various projects on cultivated lands in the highlands include traditional ditches (boyi), cut-off drains (golenta), stone and soil bunds, grass-strips and Fanya juи ${ }^{6}$. While the first three practices are traditional, grass-strips and Fanya juu represent soil-conservation practices introduced by various soil- and water-conservation projects. The importance and intensity of use of these physical soil-conservation structures, however, varies widely between the two surveyed districts.
Traditional ditches (boyi), simple drainage furrows constructed manually or by the traditional ox-drawn plough for removing excess water from a plot, are used widely in both districts, on all agro-ecologies and landforms except extremely sloping plots. The traditional ditches are largely considered as a production practice mainly designed to minimize water logging rather than a soil-conservation practice. Unlike the traditional ditches, which are believed to be a production practice, cut-off drains and stone/soil bunds are well-recognized as soil-conservation practices in both districts. Cut-off drains are semi-permanent drainage ditches constructed around a plot or parcel to prevent the water draining from upslope fields from inundating a parcel. While cut-off drains are used in both districts, however, the use of stone/soil bunds is restricted to the Debre Birhane district, where they are constructed on 42 per cent of the cultivated plots compared to 1.4 per cent in the Dendi district (Table 4). The Debre Berihan district, identified as one of the most heavily degraded areas in the central highlands and one with a tradition of using soilconservation practices, received government assistance for constructing stone and soil bunds on individual and communal holdings in the 1980s and 1990s.

In both districts, adoption of grass strips is minimal, due to its incompatibility with the land-tenure system where stubble fields after harvest are considered as communal grazing lands. Fanya juu are also rejected for allegedly aggravating water-logging.

Interestingly, despite the widely held view that smallholder farmers remove many of the soilconservation practices constructed by public 
assistance, this survey finds that only 7.7 per cent and 16.3 per cent of the owners of plots which had some type of soil conservation structure in place, which make up 3.9 per cent and 3.7 per cent of the total plots, removed these structures in the Debre Berihan and Dendi districts, respectively.

\section{Table 4}

Use of soil conservation practices by smallholder farmers on cultivated lands as per cent of plots treated (2003)

\begin{tabular}{|l|c|c|c|}
\hline Soil and water conservation practices & $\begin{array}{c}\text { Debre Birehan } \\
\mathbf{( N = 7 2 4 )}\end{array}$ & $\begin{array}{c}\text { Dendi } \\
\mathbf{( N = 4 1 7 )}\end{array}$ & $\begin{array}{c}\text { Both districts } \\
\text { combined } \\
\mathbf{( 1 1 4 1 )}\end{array}$ \\
\hline Never constructed & 50.00 & 79.38 & 60.74 \\
\hline Cut-off drains (golenta) only & & & \\
\hline Removed & 1.66 & 2.88 & 2.10 \\
\hline Reasonable condition & 0.14 & 1.68 & 0.70 \\
\hline Excellent condition & 4.14 & 14.15 & 7.80 \\
\hline Stone and soil bunds & & & 1.58 \\
\hline Removed & 2.21 & 0.48 & 1.67 \\
\hline Reasonable condition & 2.49 & 0.24 & 25.42 \\
\hline Excellent condition & 39.36 & 1.20 & 2 \\
\hline
\end{tabular}

Source: Survey data

\subsubsection{Results of the tobit adoption analysis}

This section presents the empirical results of the tobit model determining the intensity of stone/soil bund use among smallholder farmers in the Ethiopian highlands. The dependent variable is the length of the stone/soil bund constructed in meters/ha. Table 5 shows the parameter estimates of the tobit model. The likelihood ratio statistics of the tobit model are significant $(\mathrm{P}<0.001)$, suggesting the strong determining power of the independent factors taken together on the intensity of use of stone/ soil bunds among the surveyed farmers.

As noted above, the predicted values of the dependent variables from the probit perception model (equation 3 ) and the first stage estimation procedure of incidence of poverty (equation 6), which indexes the likelihood of perception of soil degradation and the likelihood of being poor, respectively, were included as explanatory variables in the tobit model given by equation (7). Note that those explanatory variables hypothesized to affect intensity of use of soil/ stone bunds and found to be significantly and strongly correlated with the predicted perception variable are excluded in the tobit model. Results on determinants of poverty from the first stage estimation procedure are given in Appendix 1.

The predicted poverty variable that indexes the probability of being poor is negatively and significantly associated with both the likelihood of adoption and intensity of stone/soil bunds. This result suggests that the higher the probability of being poor, the lower the level of investment by farmers in using stone/soil bunds. The fact that asset endowment (number of livestock per unit of land and type of house owned) has a significant negative association with the likelihood of being poor suggests that poverty in assets is an important determinant of the intensity of use of stone/soil bunds by smallholder farmers in the study area. Livestock is a source of cash and security against climatic uncertainties. Households with livestock are not only more likely to use their land much more productively but also to rent additional land from fellow farmers. The less poor households, 
i.e. those with relatively greater asset endowments, are therefore in a better position to invest in soil conservation for they have the financial resources to pay for the extra labour required for initial investments as well as to afford the short-term yield losses from reduced plot size (due to area used for erecting the stone/ soil bunds structures).

Similarly, perception of soil degradation proves to be significant to adoption of soilconservation measures, as both probability and intensity of adoption are found to vary in direct proportion to how severe soil degradation is perceived to be. These results suggest that providing reliable information and training smallholder farmers to correctly diagnose soil degradation before it becomes a major production constraint is vital if farmers are to pro-actively invest in soil-conservation practices.

Among the farm and plot characteristics, only plot size, which shows a very low correlation with the predicted probability of perception, is considered in the tobit adoption model. Plot size positively and significantly affects both the likelihood of adoption and intensity of use. Large plots are more convenient to work and provide better returns for investment, as transaction costs per unit area are lower for larger plots than for small plots. These results, therefore, call for land consolidation that allows households to have access to fewer but larger plots within the context of exploiting diverse microclimates and heterogeneous land quality.

On the other hand, access to institutional credit for the purchase of inorganic fertilizers has a negative and significant influence on both the likelihood of adoption and intensity of use of conservation measures. The results suggest that the chances of investing in permanent soilconservation structures drops by 16 per cent when a household has access to short-term institutional credit. Similarly, among those who are currently using soil-conservation structures, intensity of use is lower by 18.7 metres/ha for the average farmer with access to institutional credit compared to a household without such credit. A possible explanation is that households who have access to short-term credit for the purchase of inorganic fertilizers are likely to use these fertilizers to compensate for lost soil nutrients and hence see no need for or postpone adoption of soil-conservation measures. Various studies show the importance of improving small farmers' access to credit for improving the use of inorganic fertilizers (Yirga, Shapiro \& Demeke, 1996; Demeke, Ali \& Thomas, 1997; Croppenstedt, Demeke \& Meschi, 2003). Nonetheless, the current shortterm credit schemes that aim to raise the number of households using inorganic fertilizers and their intensity of use work against long-term investment in soil conservation, a trade-off that could be detrimental to the sustainable use of soil resources.

In contrast to access to short-term credit, land tenure security is shown in this study to be important for long-term investment in soil conservation. A household has legally defensible rights to land allotted by PA officials, but plots acquired through informal mechanisms have to be surrendered to the legal owners at the end of each cropping season. Stone/soil bunds are long-term investments, the benefits of which are realized after several years of initial investment, and hence it is sensible and rational for a household to invest more in soil conservation on land to which they are more securely entitled, that is, land allotted directly by a PA, as opposed to land acquired through informal land markets, where this security is missing. Results of the tobit analysis confirm this hypothesis, showing a higher probability and intensity of adoption of stone/soil bunds on plots acquired through the PA mechanism, which holds better security.

Government assistance for initial construction of soil-conservation practices positively and significantly influences the use of stone/soil bunds. The chances of investing in soil-conservation structures is higher by 19 per cent for a household receiving public assistance compared to a household without such assistance. This result contradicts the widely held view that assistance programmes for construction of soil-conservation structures in Ethiopia are largely unsuccessful and that such structures constructed under assistance programmes are partially or wholly removed by the people (Shiferaw \& Holden, 1998). The 
result, however, is consistent with the findings of Bekele and Drake (2003), who focus on the soil conservation research project (SCRP) site. This study's research areas are located outside the SCRP sites, and hence are broadly representative.

Access to extension measured by the number of years a household has participated in extension package programmes is positively and significantly related to the likelihood of using stone/soil bunds. In Ethiopia, agricultural extension services provided by the MOA are a major source of information on agriculture and natural resource conservation. The results therefore confirm the hypothesized positive role extension plays in natural-resource conservation in general and soil conservation in particular.

\section{Table 5}

Parameter estimates of the tobit adoption model for the intensity of stone/soil bund use Central Highlands of Ethiopia (2003)

\begin{tabular}{|l|c|c|c|c|c|c|}
\hline Variable & & & \multicolumn{2}{|c|}{ Adoption index } & \multicolumn{2}{c|}{ Expected use } \\
\hline & Coefficient & P-level & Adoption & P-level & Meter/ha & P-level \\
\hline Constant & $-269.1302^{* * *}$ & 0.000 & N.A. & N.A. & N.A. & N.A. \\
\hline Predicted perception & $264.7621^{* * *}$ & 0.000 & $0.5962^{* * *}$ & 0.000 & $67.5777^{* * *}$ & 0.000 \\
\hline Predicted poverty & $-53.1972^{*}$ & 0.073 & $-0.1198^{* *}$ & 0.047 & $-13.5780^{*}$ & 0.068 \\
\hline Plot area & $53.3290^{*}$ & 0.068 & $0.1201^{* *}$ & 0.029 & $13.6117^{*}$ & 0.064 \\
\hline Tenure & $43.3609^{* * *}$ & 0.010 & $0.0917^{* * *}$ & 0.002 & $10.4613^{* * *}$ & 0.007 \\
\hline Extension package & 5.8416 & 0.107 & $0.0132^{*}$ & 0.083 & 1.4910 & 0.102 \\
\hline Credit & $-76.2210^{* * *}$ & 0.001 & $-0.1631^{* * *}$ & 0.000 & $-18.7051^{* * *}$ & 0.000 \\
\hline Project assistance & $76.9642^{* * *}$ & 0.003 & $0.1905^{* * *}$ & 0.000 & $22.5319^{* * *}$ & 0.006 \\
\hline Diagnostics & & & & & & \\
\hline No. Observations & 1141 & & & & & \\
\hline Wald Chi-Square & $60.6200^{* * *}$ & & & & & \\
\hline $\begin{array}{l}\text { Log pseudo } \\
\text { likelihood }\end{array}$ & -2902.6423 & & & & & \\
\hline
\end{tabular}

Dependent variable: length of stone/soil bunds in metre/ha;

N.A. $=$ Not applicable;

$* * *, * *, *$ represent significant at 1 per cent, 5 per cent and 10 per cent probability levels, respectively

\section{6}

\section{Conclusions and implications of the study}

A number of significant results for policy makers are revealed by the study. First, poverty is shown to have a detrimental effect on the intensity of use of soil/stone bunds. This suggests that the poorest of the poor are less likely to use stone/soil bunds and hence more likely to deplete the soil than the less poor. The fact that education and asset endowment are negatively related to the likelihood of being poor indicates the importance of improved farmer education and asset endowment in reducing the incidence of poverty and consequently in improving adoption of stone/soil bunds among the rural poor in Ethiopia. One of the critical assets for this segment of the population is livestock, particularly oxen. Households with livestock not only use their land more productively but also are more likely to rent additional land from fellow farmers. It is therefore necessary to invest in improving farmers' education and assets, especially individual or collaborative ownership 
of oxen for poverty eradication in the highlands of Ethiopia.

Second, perception of land degradation proves to be significant in the adoption of soilconservation measures. Raising farmers' awareness through extension education and other media should form part of the overall strategy to solicit voluntary adoption of soilconservation practices by farmers in Ethiopia. Third, project assistance in sharing initial costs for constructing soil-conservation structures is an important incentive for adoption, suggesting the critical role of government assistance in improving rural income as well as contributing to reversing land degradation. Fourth, while land tenure security is found to be an essential incentive for farmers to make long-term investments in conserving soil resources, improving small farmers' access to short-term credit for the purchase of inorganic fertilizers acts as a disincentive for long-term conservation practices. This is an important trade-off with serious policy implications to be carefully evaluated. Fifth, improving smallholder farmers' skills through extension and education in diagnosing soil degradation and other soilrelated problems has a high chance of improving both the likelihood of adoption and intensity of use of soil/stone bunds.

\section{Endnotes}

1 The country is divided into 12 ethnically based regional states. Each regional state is again subdivided into several zones, and these zones into districts. Districts, also referred to as woredas, are self-governing areas consisting of a number of peasant associations, which in turn form the grass root administrative units composed of several villages (gotes).

2 In the mixed crop-livestock farming systems of the highlands, land preparation is done by oxendrawn local plough. Availability of a team (pair) of oxen among other things determines timely land preparation and planting, as well as the type and number of crops planted by a farmer in any one season, which in turn determines crop productivity.

3 The sampling frame includes households who own land (allotted by PA officials or inherited from parents) and hence pay land taxes. Newly established households (young couples) who fall in category $\mathrm{D}$ are not captured in our sample, as these are considered neither farming households nor PA members.

4 According to Feder, Just and Zilberman (1985), individual adoption (adoption at the level of the farm or firm) is defined as the degree of use of a new technology in the long-run equilibrium when the farmer has full information about the new technology and its potential.

5 All information regarding household characteristics and access to extension, credit, etc., pertain to the plot manager regardless of ownership title.

6 Fanya juu are stone/soil embankments with drainage ditchs on the lower side.

\section{References}

1 BEKELE, W. \& DRAKE, L. (2003) "Soil and water conservation decision behaviour of subsistence farmers in the Eastern Highlands of Ethiopia: a case study of the Hunde-Lafto area", Ecological Economics, 46: 437-451.

2 BOJO, J. \& CASSELLS, D. (1995) "Land degradation and rehabilitation in Ethiopia: a reassessment", AFTES Working Paper No. 17, The World Bank: Washington, DC.

3 CROPPENSTEDT, A.; DEMEKE, M. \& MESCHI, M.M. (2003) "Technology adoption in the presence of constraints: the case of fertilizer demand in Ethiopia", Review of Development Economics, 7(1): 58-70.

4 DEMEKE, M.; ALI, S. \& THOMAS, S.J. (1997) "Promoting fertilizer use in Ethiopia: the implications of improving grain market performance, input market efficiency, and farm management", Working Paper 5, Ministry of Economic Development and Cooperation Grain Market Research Project: Addis Ababa.

5 DIMARA, E. \& SKURAS, D. (2003) "Adoption of agricultural innovations as a two-stage partial observability process", Agricultural Economics, 28: 187-196.

6 ERVIN, C.A. \& ERVIN, D.E. (1982) "Factors affecting the use of soil conservation practices: hypotheses, evidence, and policy implications", Land Economics, 58(3): 277-292.

7 FAO. (1986) Ethiopian Highlands Reclamation Study Final Report, Volume I.

8 FAO. (1998) FAO Production Yearbook, Rome.

9 FEDER, G.; JUST, R.E. \& ZILBERMAN, D. (1985) "Adoption of agricultural innovations in 
developing countries: a survey", Economic Development and Cultural Change, 33: 255-298.

10 GEBREMEDHIN, B. \& SWINTON, S.M. (2000) "Reconciling food-for-work objectives: resource conservation vs. food aid targeting in Tigray, Ethiopia”, Ethiopian Journal of Agricultural Economics, 4(1\&2): 69-84.

11 GEBREMEDHIN, B. \& SWINTON, S.M. (2003) "Investment in soil conservation in northern Ethiopia: the role of land tenure security and public programs", Agricultural Economics, 29: 69-84.

12 GOULD, B.W.; SAUPE, W. \& KLEMME, R.M. (1989) "Conservation tillage: the role of farm and operator characteristics and the perception of erosion", Land Economics, 65(2): 167-182.

13 GREEN, W.H. (2000) Econometric Analysis, (4 ${ }^{\text {th }}$ ed.) Prentice-Hall: Eaglewood Cliffs, NJ.

14 GREPPERUD, S. (1996) "Population pressure and land degradation: the case of Ethiopia", Journal of Environmental Economics and Management, 30: 18-33.

15 HOLDEN, S.T.; SHIFERAW, B. \& WIK, M. (1998) "Poverty, market imperfections and time preferences: of relevance for environmental policy?" Environment and Development Economics, 3: 105-130.

16 HURNI, H. (1987) Soil Conservation Research Project, Ministry of Agriculture: Addis Ababa.

17 LONG, J.S. (1997) Regression Models for Categorical and Limited Dependent Variables: Advanced Quantitative Techniques in the Social Science, Series 7, SAGE Publications: Thousand Oaks, California.

18 MEDaC. (1999) Survey of the Ethiopian Economy: Review of Post-reform Development (1992/93-1997/98). Publisher: Addis Ababa.

19 NORRIS, E.P. \& BATIE, S.S. (1987) "Virginia farmers' soil conservation decisions: an application of Tobit analysis", Southern Journal of Agricultural Economics, 19(1): 89-97.

20 PENDER, J.; GEBREMEHIN, B. \& EHUI S. (2001) "Strategies for sustainable agricultural development in the Ethiopian highlands", American Journal of Agricultural Economics, 83: 1231-1240.

21 RAHMATO, D. (2004) "Searching for tenure security? The land system and new policy initiatives in Ethiopia”, FSS Discussion Paper No. 12, Forum for Social Studies: Addis Ababa.
22 REARDON, T. \& VOSTI, S.A. (1995) "Links between rural poverty and the environment in developing countries: asset categories and investment poverty", World Development, 23(9): 1495-1506.

23 SHIFERAW, B. \& HOLDEN, S. (2001) "Farmlevel benefits to investment for mitigating land degradation: empirical evidence from Ethiopia”, Environment and Development Economics, 6: 335-358.

24 SHIFERAW, B. \& HOLDEN, T.S. (1998) "Resource degradation and adoption of land conservation technologies in the Ethiopian highlands: a case study in Andit Tid, North Shewa", Agricultural Economics, 18: 233-247.

25 SONNEVELD, B.G.J.S. \& KEYZER, M.A. (2003) "Land under pressure: soil conservation concerns and opportunities for Ethiopia", Land Degradation \& Development, 14: 5-23.

26 SOULE, M.J.; ABEBAYEHU, T. \& KEITH, D. W. (2000) "Land tenure and the adoption of conservation practices", American Journal of Agricultural Economics, 82(4): 993-1005.

27 STOORVOGEL, J.J. \& SMALING, E.M.A. (1990) "Assessment of soil nutrient depletion in sub-Saharan Africa, 1983-2000”, Report 28, DLO Winand Starring Center for Integrated Land, Soil and Water Research: Wageningen, Netherlands.

28 TEKLU, T. \& LEMI, A. (2004) "Factors affecting entry and intensity in informal rental land markets in Southern Ethiopian highlands", Agricultural Economics, 30: 117-128.

29 VELLA, F. (1998) "Estimating models with sample selection bias: a survey", Journal of Human Resources, 33(1): 127-169.

30 WHITE, H. (1980) "A heteroskedasticityconsistent covariance matrix estimator and a direct test for heteroskedasticity", Econometrica, 48: 817-838.

31 WORLD BANK. (1994) World Development Reports, Oxford University Press: London.

32 WORLD BANK. (2004) "Ethiopia at a glance", http:/www.worldbank.org/data/ (accessed on 30 June 2004).

33 YIRGA, C.; SHAPIRO, B.I. \& DEMEKE, M. (1996) "Factors influencing adoption of new wheat technologies in Wolemera and Addis Alem areas of Ethiopia”, Ethiopian Journal of Agricultural Economics, 1(1): 63-84. 


\section{Appendix 1}

Results of the probit analyses of the determinants of poverty in the central highlands of Ethiopia (2003)

\begin{tabular}{|l|c|c|c|c|}
\hline Variables & & & \multicolumn{2}{|c|}{ Marginal effects } \\
\hline & Coefficient & P-level & Adoption index & N.A. \\
\hline Constant & $1.7981^{* * *}$ & 0.000 & 0.0035 & 0.189 \\
\hline Age & 0.0093 & 0.188 & $-0.0321^{*}$ & 0.053 \\
\hline Education & $-0.0841^{*}$ & 0.053 & $-0.0540^{* * *}$ & 0.001 \\
\hline Family size & $-0.1416^{* * *}$ & 0.001 & $-0.1538^{* *}$ & 0.046 \\
\hline House type & $-0.4064^{*}$ & 0.051 & $-0.0790^{* * *}$ & 0.000 \\
\hline Assets per ha & $-0.2071^{* * *}$ & 0.000 & & 0.663 \\
\hline Off-farm job & & & -0.0395 & 0.393 \\
\hline & -0.1029 & 0.661 & -0.0715 & \\
\hline District & -0.1878 & 0.394 & & \\
\hline Diagnostics & & & & \\
\hline Number of observations & 229 & & & \\
\hline Wald Chi-Square & $47.0100^{* * *}$ & & & \\
\hline Pseudo R-Square & 0.2253 & & & \\
\hline Log pseudo-likelihood & -119.5176 & & & \\
\hline
\end{tabular}

Dependent variable: poor $=1$, less poor $=0$;

N.A. $=$ Not applicable

$* * *, * *, *$ represent significance at 1 per cent, 5 per cent and 10 per cent probability levels, respectively 